\title{
Role of Protein Kinase in the Substance P-Induced Inhibition of the GABA Response in Neurons of the Bullfrog Dorsal Root Ganglia
}

\author{
KEI YAMADA*†, ZHENG-XIONG XI* AND TAKASHI AKASU* \\ *Departments of Physiology and ${ }^{\dagger}$ Orthopaedics, Kurume University \\ School of Medicine, Kurume 830, Japan
}

Received for publication December 8, 1995

\begin{abstract}
Key words: substance $P$, dorsal root ganglia, whole-cell recordings, $\mathrm{GABA}_{\mathrm{A}}$ receptor, $\mathrm{PKA}, \mathrm{PKC}$
\end{abstract}

The $\mathrm{GABA}_{\mathrm{A}}$ receptor is known to be the site of action for a variety of drugs with hypnotic, anaesthetic and anticonvulsant properties (see Reviews, Bormann, 1988; Sieghart, 1992; Macdonald and Olsen, 1994; Smith and Olsen, 1995). The function of the $\mathrm{GABA}_{\mathrm{A}}$ receptor is also modulated by intracellular substances, such as $\mathrm{Ca}^{2+}$ in DRG neurons (Inoue et al. 1986; Taleb et al. 1987; Behrends et al. 1988; Llano et al. 1991; Kano et al. 1992; Mulle et al. 1992) and ATP in guinea pig hippocampal neurons and chick spinal cord neurons (Gyenes et al. 1988, 1994; Stelzer et al. 1988; Shirasaki et al. 1992). Phosphorylation and dephosphorylation of receptorassociated chloride channels have been considered as an important step in the modulation of $\mathrm{GABA}_{\mathrm{A}}$ receptor function (Nestler and Greengard, 1984; Stelzer et al. 1988; Chen et al. 1990; Chen and Wong, 1995). Recently, it was reported that substance P (SP) inhibited a GABAinduced inward current in primary afferent neurons of the bullfrog dorsal root ganglia (DRG) (Yamada and Akasu,
1996). In the present study, a role of a protein kinase in the SP-induced inhibition of the $\mathrm{GABA}_{\mathrm{A}}$ response in DRG neurons was observed.

Neurons were dissociated from the bullfrog DRG (Rana catesbeiana) in a Ringer solution containing trypsin (Sigma type XI, $2.5 \mathrm{mg} / \mathrm{ml}$ ) and collagenase (Sigma type A, $0.5 \mathrm{mg} / \mathrm{ml}$ ) (Tokimasa and Akasu, $1990 a, b$ ). The Ringer solution had the following composition (mM): $\mathrm{NaCl}, 112 ; \mathrm{KCl}, 2$; $\mathrm{CaCl}_{2}, 1.8$; N-2-hydroxyethylpiperazine-N'-2-ethanesulfonic acid (HEPES), 4 and tris (hydroxymethyl) aminomethane (Tris), 1. Cells with diameters greater than $50 \mu \mathrm{m}$ (A-type cells) were used for whole-cell patchclamp recordings. Pipettes for the whole-cell clamp had tip resistances of 3-6 $\mathrm{M} \Omega$, when filled with a pipette solution having the following composition (mM): $\mathrm{KCl}, 100 ; \mathrm{MgCl}_{2}, 4$; ATP, 5; BAPTA, ethylene glycol-bis ( $\beta$-aminoethyl ether) N, N, N', N'-tetraacetic acid (EGTA), 1; and HEPES (sodium salt), 2.5 (pH adjusted with $\mathrm{KOH}$ to 7.0 ). All experiments were carried out at $22-24^{\circ} \mathrm{C}$. The

Reprint requests to: Dr. T. Akasu, Department of Physiology, Kurume University School of Medicine, 67 Asahi-machi, Kurume 830, Japan. Tel: +81-942-31-7543 Fax: +81-942-31-7728 
statistics are expressed as mean \pm S.E.M. for the cells tested. The $\mathrm{pH}$ of the superfusate was adjusted to 7.2.

DRG neurons were voltage-clamped at $-60 \mathrm{mV}$ in a whole-cell configuration. The addition of GABA $(1 \mu \mathrm{M}-1 \mathrm{mM})$ to the superfusing solution for $5 \mathrm{~s}$ induced an inward current $\left(\mathrm{I}_{\mathrm{GABA}}\right)$ associated with an increased membrane conductance. The $\mathrm{I}_{\mathrm{GABA}}$ was blocked by the bathapplication of picrotoxin $(100 \mu \mathrm{M})$ or bicuculline $(100 \mu \mathrm{M})$. Repeated applications of GABA at intervals of 5-10 min showed no significant 'run down' of the inward current for $1 \mathrm{~h}$. The bath-application of SP (100 nM) induced an inward current associated with a decreased membrane conductance in Ringer solution containing TTX (1 $\mu \mathrm{M})$ (Ishimatsu, 1994). The $I_{G A B A}$ was depressed during the application of SP (Fig. 1). At a concentration of $1 \mu \mathrm{M}$, SP reduced the $\mathrm{I}_{\mathrm{GABA}}$ by $38 \pm 6 \%(\mathrm{n}=8)$. When GABA $(1 \mathrm{mM})$ was continuously applied for more than $1 \mathrm{~min}$, the response rapidly reached a peak amplitude and then slowly declined.

A.

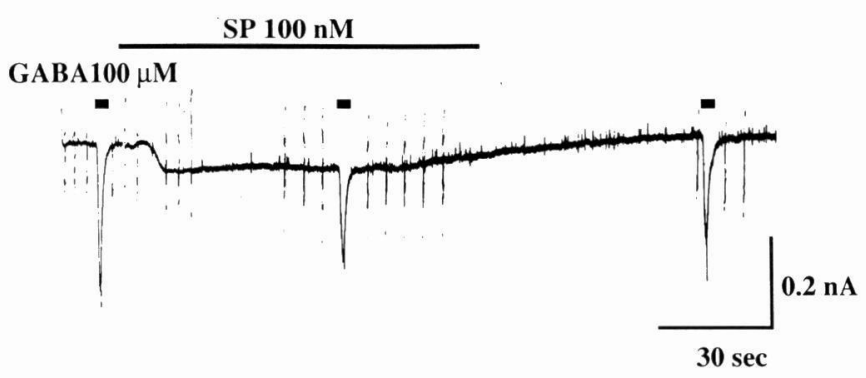

B.

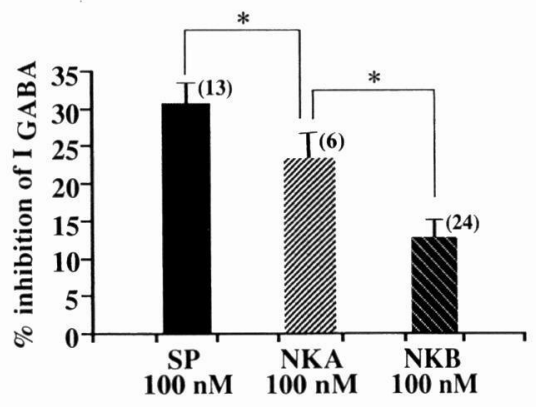

Fig. 1. Modulation of $\mathrm{GABA}_{\mathrm{A}}$ receptor responses by tachykinins. A: Effect of SP $(100 \mathrm{nM})$ on the GABA-induced inward current. GABA was applied in the bath for $5 \mathrm{~s}$, as indicated by the short horizontal bars. The period of the bath-application of SP is indicated by the long horizontal bar. B: Effects of SP, NKA and NKB on the GABA-induced current. The ordinate indicates \% inhibition of the GABA current. The vertical line on each column indicates the SE of the mean. The number of experiments is shown in parentheses. Asterisks indicate statistical significance $(\mathrm{P}<0.05)$. 
Such a transient response during the prolonged application of GABA probably results from either a desensitization of the $\mathrm{GABA}_{\mathrm{A}}$ receptors and/or a redistribution of $\mathrm{Cl}^{-}$across the plasma membranes of the neurons (Akaike et al. 1987). In DRG neurons, the decay of the current observed during the application of GABA can be described by a single exponential with a time-constant of $38 \pm$ $5 \mathrm{~s}(\mathrm{n}=5)$. The time-constant of the decay phase of the $\mathrm{I}_{\mathrm{GABA}}$ was not significantly changed by SP. Neurokinin A (NKA, 100 $\mathrm{nM})$, a neurokinin-1 $\left(\mathrm{NK}_{1}\right)$ receptor agonist, also induced inward currents with amplitudes similar to those produced by SP (100 nM) $(n=3)$. NKA (100 $n M$ ) decreased the amplitude of the $I_{\mathrm{GABA}}$ by $28 \pm 3 \%(n=6)$. In neurons treated with L-703,606, a potent $\mathrm{NK}_{1}$ receptor antagonist, SP decreased the $\mathrm{I}_{\mathrm{GABA}}$ by only 10 $\pm 3 \%(n=4)$. These results indicate that SP depresses the GABA current through the activation of an $\mathrm{NK}_{1}$ tachykinin receptor. Bath-application of forskolin $(10 \mu \mathrm{M})$, an activator of adenylyl cyclase, for $10 \mathrm{~min}$ reduced the $\mathrm{I}_{\mathrm{GABA}}$ in DRG neurons by $41 \pm 5 \%(n=5)$. Db-cyclic AMP $(200 \mu \mathrm{M})$, a membrane permeable analogue of cyclic AMP, also depressed the $\mathrm{I}_{\mathrm{GABA}}$ by $38 \pm 7 \%(\mathrm{n}=10)$. H-9 $(40 \mu \mathrm{M})$, a protein kinase A (PKA) inhibitor, was applied to the internal solution through the recording electrode. $\mathrm{H}-9$ did not consistently affect the inhibitory action of SP on the $\mathrm{I}_{\mathrm{GABA}}$ (Fig. 2). Similarly, another PKA inhibitor, HA-1004, had no effect on the SP response. To test whether protein kinase $\mathrm{C}$ mediated the SPinduced inhibition of the $\mathrm{I}_{\mathrm{GABA}}, \mathrm{H}-7$ (200 $\mu \mathrm{M}$ ), a protein kinase $\mathrm{C}$ inhibitor, was applied to the ganglion cells by diffusion through a whole-cell patch-pipette. In neurons treated with $\mathrm{H}-7$, SP (100 nM) decreased the $\mathrm{I}_{\mathrm{GABA}}$ by only $7 \pm 5 \%(\mathrm{n}=4)$ (Fig. 2). In DRG neurons treated with W$7(100 \mu \mathrm{M})$, a $\mathrm{Ca}^{2+} /$ calmodulin inhibitor, SP (100 nM) depressed the $\mathrm{I}_{\mathrm{GABA}}$ by $27 \pm$ $3 \%(\mathrm{n}=5)$.

The present study has shown that SP suppresses the $\mathrm{GABA}_{\mathrm{A}}$ response in acutely dissociated neurons of the bullfrog DRG. The SP-induced depression of the $I_{\text {GABA }}$ does not result from either an enhanced desensitization of the $\mathrm{GABA}_{\mathrm{A}}$ receptors or a re-distribution of chloride across the cell membrane (Akaike et al. 1987). L-703, 606, a non-peptide antagonist at the $\mathrm{NK}_{1}$ receptor, also reduced the inhibition of the $I_{\mathrm{GABA}}$ by SP. A

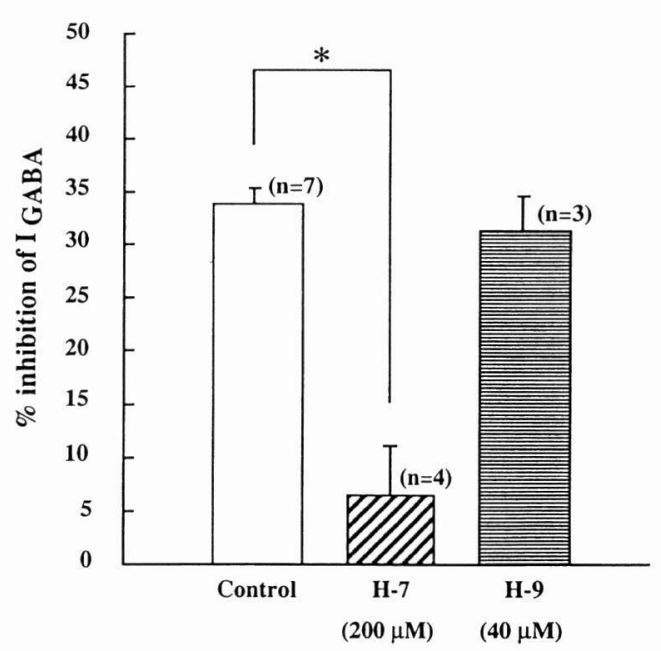

Fig. 2. Role of protein kinase $\mathrm{C}$ in the SPinduced inhibition of the $\mathrm{I}_{\mathrm{GABA}}$. The ordinate indicates \% inhibition of the $\mathrm{I}_{\mathrm{GABA}}$ produced by SP $(100 \mathrm{nM}) . \mathrm{H}-9(40 \mu \mathrm{M})$ and H-7 $(200 \mu \mathrm{M})$ were applied, intracellularly, through a recording patch-pipette. The vertical line in each column indicates the $\mathrm{SE}$ of the mean. The asterisk indicates statistical significance $(\mathrm{P}<$ 0.05). 
related agonist for tachykinin receptors, NKA, also produced an inhibition of the $\mathrm{I}_{\mathrm{GABA}}$. These results indicate that the SP receptors responsible for the inhibition of the $\mathrm{I}_{\mathrm{GABA}}$ are similar to the $\mathrm{NK}_{1}$ type (Watson and Girdlestone, 1995). It has been shown that SP produces an inward current by suppressing the M-current through an activation of a G-protein in frog sympathetic ganglia (Pfäffinger, 1988; Lopez and Adams, 1989) and bullfrog DRG neurons (Ishimatsu, 1994). Pfäffinger (1988) has demonstrated that the SP-induced inhibition of $\mathrm{I}_{\mathrm{M}}$ occurs independent of $\mathrm{PKC}$ but is mediated directly by a G-protein. The present study demonstrates that the SP-induced inhibition of $\mathrm{I}_{\mathrm{GABA}}$ was blocked by a PKC inhibitor, H-7. Although db-cyclic AMP and forskolin, an adenylyl cyclase activator, depressed the $\mathrm{I}_{\mathrm{GABA}}$; a PKA inhibitor, $\mathrm{H}-9$, did not prevent the SP-induced inhibition of the $\mathrm{I}_{\mathrm{GABA}}$. It can be concluded that the SP-induced inhibition of the $\mathrm{I}_{\mathrm{GABA}}$ is mediated by a diffusible messenger, probably PKC. There are several reports relating to the signal transduction pathway for the SP effect. SP accelerates the turnover of inositol polyphosphate metabolism by activating phospholipase C (PLC) (Hanley et al. 1980; Watson and Downes, 1983; Pfäffinger, 1988). A G-protein may activate PLC, and an increase in PLC activity can lead to the activation of PKC via diacylglycerol (Nishizuka et al. 1991). Further experiments using more specific PKC inhibitors are necessary to elucidate this hypothesis.

Acknowledgments: This study was supported primarily by a Grant-in-Aid for Research from The Ishibashi Foundation and a Grant-in-Aid for Scientific Research from the Ministry of Education, Science and Culture of Japan.

\section{References}

Akaike N, Inomata $\mathrm{N}$, and Tokutomi N Contribution of chloride shifts to the fade of $\gamma$-aminobutyric acid-gated currents in frog dorsal root ganglion cells. J Physiol 1987; 391:219-234.

Behrends JC, Maruyama T, Tokutomi N, and Akaike N. $\mathrm{Ca}^{2+}$-mediated suppression of the GABA-response through modulation of chloride channel gating in frog sensory neurones. Neurosci Lett 1988; 86:311-316.

Bormann J. Electrophysiology of $\mathrm{GABA}_{\mathrm{A}}$ and $\mathrm{GABA}_{\mathrm{B}}$ receptor subtypes. TINS 1988; 11:112116.

Chen QX, Stelzer A, Kay AR, and Wong RKS. $\mathrm{GABA}_{\mathrm{A}}$ receptor function is regulated by phosphorylation in acutely dissociated guinea-pig hippocampal neurones. J Physiol 1990; 420:207-221.

Chen QX, and Wong RKS. Suppression of $\mathrm{GABA}_{\mathrm{A}}$ receptor responses by NMDA application in hippocampal neurones acutely isolated from the adult guinea-pig. J Physiol 1995; 482:353-362.

Gyenes M, Farrant M, and Farb DH. "Run-

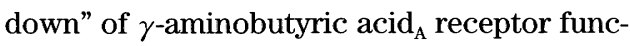
tion during whole-cell recording: a possible role for phosphorylation. Mol Pharmacol 1988; 34:719-723.

Gyenes M, Wang Q, Gibbs TT, and Farb DH. Phosphorylation factors control neurotransmitter and neuromodulator actions at the $\gamma$ aminobutyric acid type A receptor. Mol Pharmacol 1994; 46:542-549.

Hanley MR, Lee CM, Michell RH, and Jones LM. Similar effects of substance $\mathrm{P}$ and related peptides on salivation and on phosphatidylinositol turnover in rat salivary glands. Mol Pharmacol 1980; 18:78-83.

Inoue $\mathrm{M}$, Oomura Y, Yakushiji T, and Akaike N. Intracellular calcium ions decrease the affin- 
ity of the GABA receptor. Nature 1986; 324: 156-158.

Ishimatsu M. Substance P produces an inward current by suppressing voltage-dependent and -independent $\mathrm{K}^{+}$currents in bullfrog primary afferent neurons. Neurosci Res 1994; 19:9-20.

Kano M, Rexhausen U, Dreessen J, and Konnerth A. Synaptic excitation produces a long-lasting rebound potentiation of inhibitory synaptic signals in cerebellar Purkinje cells. Nature 1992; 356:601-604.

Llano I, Leresche N, and Marty A. Calcium entry increases the sensitivity of cerebellar Purkinje cells to applied GABA and decreases inhibitory synaptic currents. Neuron 1991; 6:565-574.

Lopez HS, and Adams PR. A G protein mediates the inhibition of the voltage-dependent potassium M current by mescarine, LHRP, substance $\mathrm{P}$ and UTP in bullfrog sympathetic neurons. Eur J Neurosci 1989; 1:529-542.

Macdonald RL, and Olsen RW. GABA $\mathrm{A}_{\mathrm{A}}$ receptor channels. Annu Rev Neurosci 1994; 17:569602.

Mulle C, Choquet D, Korn H, and Changeux J-P. Calcium influx through nicotinic receptor in rat central neurons: its relevance to cellular regulation. Neuron 1992; 8:135-143.

Nestler EJ, and Greengard P. Protein Phosphorylation in the Nervous System, John Wiley \& Sons, New York, 1984.

Nishizuka Y, Shearman MS, Oda T, Berry N, Shinomura $\mathrm{T}$ et al. Protein kinase $\mathrm{C}$ family and nervous function. Prog Brain Res 1991; 89:125-141.

Pfäffinger P. Muscarine and t-LHRH suppress M-current by activating an IAP-insensitive Gprotein. J Neurosci 1988; 8:3343-3353.
Shirasaki T, Aibara K, and Akaike N. Direct modulation of $\mathrm{GABA}_{\mathrm{A}}$ receptor by intracellular ATP in dissociated nucleus tractus solitarii neurones of rat. J Physiol 1992; 449:551-572.

Sieghart W. GABA $A_{A}$ receptors: ligand-gated $\mathrm{Cl}^{-}$ ion channels modulated by multiple drugbinding sites. TIPS 1992; 13:446-450.

Smith GB, and Olsen RW. Functional domains of $\mathrm{GABA}_{\mathrm{A}}$ receptors. TIPS 1995; 16:162-168.

Stelzer A, Kay $\mathrm{AR}$, and Wong RKS. $\mathrm{GABA}_{\mathrm{A}^{-}}$ receptor function in hippocampal cells is maintained by phosphorylation factors. Science 1988; 241:339-341.

Taleb O, Trouslard J, Demeneix BA, Feltz P, Bossu J-L et al. Spontaneous and GABAevoked chloride channels on pituitary intermediate lobe cells and their internal $\mathrm{Ca}$ requirements. Pflügers Arch 1987; 409:620631.

Tokimasa T, and Akasu T. Cyclic AMP regulates an inward rectifying sodium-potassium current in dissociated bull-frog sympathetic neurones. J Physiol 1990a; 420:409-429.

Tokimasa T, and Akasu T. ATP regulates muscarine-sensitive potassium current in dissociated bull-frog primary afferent neurones. J Physiol 1990b; 426:241-264.

Watson SP, and Downes CP. Substance P induced hydrolysis of inositol phospholipids in guinea-pig ileum and rat hypothalamus. Eur J Pharmacol 1983; 93:245-253.

Watson S, and Girdlestone D. Receptor \& ion channel nomenclature supplement. TIPS 1995; 6th ed.

Yamada K, and Akasu T. Substance $P$ modulates the $\mathrm{GABA}_{\mathrm{A}}$ receptor function via protein kinase $\mathrm{C}$ in bullfrog primary afferent neurons. Jpn J Physiol 1996; in press. 